\title{
INSTITUTIONALIZATION OF PUBLIC POLICY: ANALYSIS OF SOCIO-POLITICAL PRACTICES IN THE REGIONS OF THE RUSSIAN FEDERATION ${ }^{1}$
}

\author{
Sergey A. Pankratov \\ Volgograd State University, Volgograd, Russian Federation \\ Ekaterina G. Kirsanova \\ Lomonosov Moscow State University, Moscow, Russian Federation \\ Elena N. Seyfieva \\ Novorossiysk Branch of Financial University under the Government of the Russian Federation, \\ Novorossiysk, Russian Federation
}

\begin{abstract}
The article analyzes the progress of the research project "Strategies, Innovative Technologies of Institutionalization and Functioning of Public Policy in the Volgograd Region" conducted by the scientists of the Volgograd State University within the framework of the RFBR Regional Competition "Volga Lands in the History and Culture of Russia". Attention is focused on the cooperation of the research team with Russian regional scientific centers, as well as deputies of the State Duma of the Federal Assembly of the Russian Federation.

S.A. Pankratov analyzed the theoretical and empirical basis of the research work of the scientific and educational center. E.G. Kirsanova characterized the practices of interaction between researchers and representatives of public policy at the regional and federal levels. E.N. Seyfieva identified the directions of cooperation of the Volgograd scientists with research centers in the regions of Russia.

Key words: public policy, civil society, governmental authorities, communicative technologies, resources, RFBR grant, models of interaction.
\end{abstract}

Citation. Pankratov S.A., Kirsanova E.G., Seyfieva E.N. Institutionalization of Public Policy: Analysis of Socio-Political Practices in the Regions of the Russian Federation. Vestnik Volgogradskogo gosudarstvennogo - universiteta. Serija 4, Istorija. Regionovedenie. Mezhdunarodnye otnoshenija [Science Journal of Volgograd ¿ State University. History. Area Studies. International Relations], 2017, vol. 22, no. 6, pp. 188-192. (in Russian). if DOI: https://doi.org/10.15688/jvolsu4.2017.6.20

\section{ИНСТИТУЦИОНАЛИЗАЦИЯ ПУБЛИЧНОЙ ПОЛИТИКИ: АНАЛИЗ СОЦИАЛЬНО-ПОЛИТИЧЕСКИХ ПРАКТИК В РЕГИОНАХ РОССИЙСКОЙ ФЕДЕРАЦИИ ${ }^{1}$}

\author{
Сергей Анатольевич Панкратов
}

Волгоградский государственный университет, г. Волгоград, Российская Федерация

\section{Екатерина Геннадьевна Кирсанова}

Московский государственный университет им. М.В. Ломоносова, г. Москва, Российская Федерация 


\section{Елена Николаевна Сейфиева}

Новороссийский филиал Финансового университета при Правительстве Российской Федерации, г. Новороссийск, Российская Федерация

Аннотация. В статье анализируется ход реализации учеными Волгоградского государственного университета научно-исследовательского проекта «Стратегии, инновационные технологии институционализации и функционирования публичной политики в Волгоградском регионе», выполняемого в рамках регионального конкурса РФФИ «Волжские земли в истории, культуре России». Акцентируется внимание на сотрудничестве исследовательского коллектива с российскими региональными научными центрами, а также депутатами Государственной думы Федерального собрания РФ.

С.А. Панкратов проанализировал научно-теоретическую и эмпирическую базу исследовательской работы научно-образовательного центра. Е.Г. Кирсанова охарактеризовала практики взаимодействия исследователей с действующими представителями публичной политики на региональном и федеральном уровнях. Е.Н. Сейфиева выделила направления сотрудничества волгоградских ученых с научными центрами в субъектах РФ.

Ключевые слова: публичная политика, гражданское общество, органы государственной власти, коммуникативные технологии, ресурсы, грант РФФИ, модели взаимодействия.

Цитирование. Панкратов С.А., Кирсанова Е.Г., Сейфиева Е.Н. Институционализация публичной политики: анализ социально-политических практик в регионах Российской Федерации // Вестник Волгоградского государственного университета. Серия 4, История. Регионоведение. Международные отношения. - 2017. T. 22, № 6. - C. 188-192. - DOI: https://doi.org/10.15688/jvolsu4.2017.6.20

Столетний юбилей Великой русской революции выступил отправной точкой для актуализации дискуссии в научном и гражданском сообществе о допустимости и применимости технологий насильственных изменений в различных сферах российской действительности. Более того, целый ряд отечественных и зарубежных исследователей отстаивают точку зрения о том, что одной из важнейших причин Русской революции была неспособность правящей элиты и государства в целом к диалогу с различными социальными группами, а также недооценка значимости влияния гражданского общества на принятие политических решений $[2 ; 4 ; 5]$. В этой связи поиск эффективных технологий согласования интересов общества и государства (институционализации сферы публичной политики) в рамках реализации нынешнего этапа этатистской модели модернизации выступает как логический ответ на исторические уроки прошлого и социально-политические вызовы современности. При этом, как показывает исторический опыт развития России, «вызовы затрагивают наиболее важные, коренные интересы государства, связанные с его безопасностью, а ответы на них воплощаются в крупных структурных сдвигах, призванных изменить направление и характер его развития; соответствующая деятельность государства, выраженная в сериях правительственных мероприятий, не может не вовлекать в них широкие социальные силы» [1, с. 630].

Именно в этом контексте следует рассматривать значимость выполнения коллективом научно-образовательного центра (НОЦ) «Модернизация многомерного социально-политического пространства современной России» при Волгоградском государственном университете научно-исследовательского проекта «Стратегии, инновационные технологии институционализации и функционирования публичной политики в Волгоградском регионе» в рамках регионального конкурса РФФИ «Волжские земли в истории, культуре России».

Актуальность данного исследования определяется целым рядом факторов, в том числе необходимостью: анализа специфики складывающегося институционального дизайна публичного пространства в различных субъектах РФ; выявления наиболее эффективных ресурсов и моделей взаимодействия органов власти и институтов гражданского общества, различных групп населения в условиях противоречивости проявления протестного поведения системной / внесистемной оппозиции; расширения практик участия населения Волгоградской области в выработке, принятии и реализации политических решений, направленных на повышение качества и уров- 
ня жизни, обеспечение стабильности и безопасности жизнедеятельности.

Научная проблема, на решение которой направлен проект, заключается в том, что одной из серьезнейших угроз процессу обеспечения стабильного развития российского общества и государства выступает увеличение институциональных искажений публичной политики, технологическая и содержательная деформация коммуникативных связей между различными группами граждан, их объединениями с органами государственной власти и местного самоуправления. При этом существует значительная поляризация между субъектами РФ по уровню институционализации публичной политики, эффективности использования технологий и ресурсов ее осуществления в рамках сложившихся региональных политических режимов.

Научная новизна данного проекта связана с преодолением доминирования управленческо-административного подхода к исследованию институционализации публичной политики в РФ. В рамках гранта впервые ставится задача обосновать институциональные искажения в публичном политическом пространстве российских регионов, и в частности в Волгоградской области, а также предложить систему приоритетных стратегий, ресурсов и инновационных технологий повышения эффективности реализации региональной публичной политики.

Для решения поставленных задач исследовательским коллективом используется комплекс теоретических и эмпирических (качественных и количественных) методов: дискурс-анализ проблемного поля общественных дискуссий о специфике институционализации публичной политики в РФ и ее субъектах; фокус-группы с представителями институциональных / неинституциональных акторов публичной политики Волгоградского региона; метод наблюдения и описания случаев (case study) с целью углубленного изучения в регионе технологий коммуникативного взаимодействия органов государственной власти и местного самоуправления с представителями гражданского общества; направленный ассоциативный эксперимент (метод свободных ассоциаций) для выявления типичных / специфических практик, ассоциированных стерео- типов (установок) действующих и потенциальных субъектов публичной политики; анкетный опрос различных групп населения; фокусированные интервью с представителями органов власти на государственном и муниципальном уровнях; глубинные интервью с представителями институтов гражданского общества; контент-анализ документальных источников; моделирование поведенческих ситуаций.

Важнейшей составляющей в реализации проекта выступило посещение исследовательским коллективом НОЦ Государственной думы Федерального собрания РФ, знакомство с законотворческой деятельностью комитетов, процедурными особенностями принятия законов парламентариями, технологиями реализации наказов избирателей. Содержательный и полезный обмен мнениями по актуальным проблемам современного политического процесса состоялся на встрече политологов ВолГУ с депутатами: председателем комитета по федеративному устройству и вопросам местного самоуправления А.Н. Диденко, членом комитета по физической культуре, спорту, туризму и делам молодежи Д.А. Свищевым, членом комитета по бюджету и налогам, представляющим в Государственной думе Волгоградскую область, А.А. Носовым. Было принято решение расширять формы сотрудничества, в том числе и в рамках реализации гранта РФФИ [3].

Успешному достижению цели проекта способствует сотрудничество волгоградских исследователей с научными коллективами ЮФО (г. Астрахань, Краснодар, Новороссийск, Ростов-на-Дону), СКФО (г. Пятигорск, Ставрополь), Приволжского и Центрального федеральных округов (г. Казань, Москва, Саратов), СЗФО (г. Калининград, Санкт-Петербург). Основные результаты проекта будут обнародованы путем: подготовки коллективной монографии; публикации статей в изданиях, индексируемых в международных и российских базах цитирования, в журналах, рекомендованных ВАК Минобрнауки РФ; опубликования материалов и тезисов выступлений на международных, всероссийских и региональных конференциях.

Таким образом, проект имеет, с одной стороны, фундаментальный характер, то есть предполагает дальнейшее концептуальное ос- 
мысление функциональной специфики института публичной политики в условиях диверсификации принципов демократии, механизмов осуществления народовластия, обеспечения включенности граждан в реальный политический процесс. С другой стороны, носит поисковый и прикладной характер, то есть предусматривает подготовку аналитических материалов для органов государственной власти и институтов гражданского общества, обосновывающих инновационные модели оптимизации и реализации публичной политики в российских регионах, и в частности в Волгоградской области.

\section{ПРИМЕЧАНИЕ}

1 Работа выполнена при финансовой поддержке РФФИ и Администрации Волгоградской области, проект № 17-13-34039 «Стратегии, инновационные технологии институционализации и функционирования публичной политики в Волгоградском регионе».

\section{СПИСОК ЛИТЕРАТУРЫ}

1. Алексеев, В. В. Большие вызовы в истории имперской России: цивилизационное и геополитическое измерение / В. В. Алексеев, К. И. Зубков, И. В. Побережников // QUAESTIO ROSSICA. 2017 - Т. 5, № 3. - С. 619-634.

2. Гайда, Ф. А. Либеральная оппозиция на путях к власти (1914 - весна 1917 г.). - М. : РОССПЭН, 2003. -432 c.

3. Депутаты Дмитрий Свищев, Александр Носов и Алексей Диденко встретились со студентами Волгоградского государственного университета. Электрон. текстовые дан. - Режим доступа: http://
www.komitet6.km.duma.gov.ru/Novosti/item/427049/ (дата обращения: 01.06.2017). - Загл. с экрана.

4. Петров, Ю. А. Россия накануне Великой революции 1917 г.: современные историографические тенденции / Ю. А. Петров // Российская история. -2017 . - № 2. - С. 3-16.

5. Розов, Н. С. Вектор Русской революции 1917 г. - модернизация или контрмодернизация? / Н. С. Розов // Политические исследования. -2017. № 2. - C. 8-25.

\section{REFERENCE}

1. Alekseev V.V., Zubkov K.I., Poberezhnikov I.V. Bolshie vyzovy $\mathrm{v}$ istorii imperskoy Rossii: tsivilizatsionnoe i geopoliticheskoe izmerenie [Great Challenges in the History of Imperial Russia: Civilizational and Geopolitical Dimension]. QUAESTIO ROSSICA, 2017, vol. 5, no. 3, pp. 619-634.

2. Gayda F.A. Liberalnaya oppozitsiya na putyakh $k$ vlasti (1914 - vesna 1917 g.) [Liberal Opposition on the Ways to Power (1914 - Spring 1917)]. Moscow, ROSSPEN Publ., 2003. 432 p.

3. Deputaty Dmitriy Svishchev, Aleksandr Nosov i Aleksey Didenko vstretilis so studentami Volgogradskogo gosudarstvennogo universiteta [Deputies Dmitry Svishchev, Alexander Nosov and Alexey Didenko Met with Students of Volgograd State University]. URL: http://www.komitet6.km.duma. gov.ru/Novosti/item/427049/ (accessed June 1, 2017).

4. Petrov Yu.A. Rossiya nakanune Velikoy revolyutsii 1917 g.: sovremennye istoriograficheskie tendentsii [Russia on the Eve of the Great Revolution of 1917: Modern Historiographic Tendencies]. Rossiyskaya istoriya, 2017, no. 2, pp. 3-16.

5. Rozov N.S. Vektor Russkoy revolyutsii 1917 g.--modernizatsiya ili kontrmodernizatsiya? [The Vector of the Russian Revolution of 1917 Modernization or Counter-Modernization?]. Politicheskie issledovaniya, 2017, no. 2, pp. 8-25.

\section{Information about the Authors}

Sergey A. Pankratov, Doctor of Sciences (Politics), Professor, Head of Department of International Relations, Political Science and Area Studies, Volgograd State University, Prosp. Universitetsky, 100, 400062 Volgograd, Russian Federation, pankratov@volsu.ru, https://orcid.org/0000-0002-1733-730X

Ekaterina G. Kirsanova, Candidate of Sciences (Politics), Assistant, Department of Russian Politics, Lomonosov Moscow State University, Prosp. Lomonosovsky, 27, bld. 4, 119991 Moscow, Russian Federation, e-kirsanova@mail.ru, https://orcid.org/0000-0002-7708-2978

Elena N. Seyfieva, Candidate of Sciences (Politics), Associate Professor, Department of Informatics, Mathematics and Humanities, Director of Novorossiysk Branch of Financial University under the Government of the Russian Federation, Vidova St., 56, 353907 Novorossiysk, Russian Federation, Ken_lena@mail.ru, https://orcid.org/0000-0001-8726-9106 


\section{ХРОНИКА НАУЧНОЙ ЖИЗНИ}

\section{Информация об авторах}

Сергей Анатольевич Панкратов, доктор политических наук, профессор, заведующий кафедрой международных отношений, политологии и регионоведения, Волгоградский государственный университет, просп. Университетский, 100, 400062 г. Волгоград, Российская Федерация, pankratov@volsu.ru, https://orcid.org/0000-0002-1733-730X

Екатерина Геннадьевна Кирсанова, кандидат политических наук, ассистент кафеды российской политики, Московский государственный университет им. М.В. Ломоносова, просп. Ломоносовский, 27, корпус 4, 119991 г. Москва, Российская Федерация, e-kirsanova@mail.ru, https:// orcid.org/0000-0002-7708-2978

Елена Николаевна Сейфиева, кандидат политических наук, директор филиала, доцент кафедры информатики, математики и общегуманитарных наук, Новороссийский филиал Финансового университета при Правительстве Российской Федерации, ул. Видова, 56, 353907 г. Новороссийск, Российская Федерация, Ken_lena@mail.ru, https://orcid.org/0000-0001-8726-9106 